\title{
OPTIMASI KEKUATAN TARIK PROSES ELECTROPLATING SS400 MENGGUNAKAN METODE TAGUCHI
}

\section{OPTIMIZATION OF TENSILE STRENGTH OFELECTROPLATED SS400 USING TAGUCHI METHOD}

\author{
Muhammad Sholihul Amin ${ }^{1}$, Mahros Darsin ${ }^{2}$, Andi Sanata ${ }^{3}$ \\ ${ }^{1}$ Alumni Program Studi S-1 Teknik Mesin Universitas Jember \\ 2,3Staf Pengajar Jurusan Teknik Mesin Fakultas Teknik Universitas Jember \\ Jl. Kalimantan No. 37 Kampus Tegalboto, Jember 68121, (0331) 484977 \\ Email: solikulamin17@gmail.com \\ ${ }^{2}$ Correspondence email: mahros.teknik@unej.ac.id \\ Email:andisanata@unej.ac.id
}

Diterima : $02-01-2020$

Direvisi : $17-02-2020$

Disetujui : $06-03-2020$

\begin{abstract}
ABSTRAK
Material SS400 merupakan logam jenis baja karbon rendah yang biasa digunakan dalam industri kontruksi ataupun jembatan yang bersentuhan langsung dengan lingkungan sekitar. Akibatnya sifat mekanis serta mutu material SS400 akan menurun seiring waktu pemakaian. Riset lain sebelumnya membuktikan bahwa selain memperbaiki sifat tahan korosi, electroplating mampu menaikkan sifat mekanis baja yang dilapisi. Maka perlu upaya yang serupa untuk menaikkan sifat mekanis SS400 ini dengan caraelectroplating. Tujuan dari penelitian ini adalah untuk mengoptimasi kekuatan tarik yang diperoleh dari hasilelectroplating baja SS400 dengan pelapis nikel.Metode Taguchi L9 digunakan dengan variasi parameter kuat arus, suhu, dan waktu dengan masing-masing terdiri atas tiga level.Masingmasing kombinasi diulang tiga kali.Bahan baja dibentuk menjadi sampel uji tarik standar ASTM E8 sebelum pelapisan.Uji tarik dilakukan dengan mesin uji tarik Zwick / Roel Z100.Analisis S/N ratio dilanjutkan dengan ANOVA membuktikan bahwa suhu, arus dan waktu berpengaruh terhadap kekuatan tarik masing-masing sebesar 62,57\%; 13,63\%; dan 10,89\%. Sedangkan kombinasi parameter electroplatingyang paling optimal adalah pada kuat arus 3 ampere, suhu $45^{\circ} \mathrm{C}$, dan waktu 15 menit dengan kekuatan tarik sebesar 610,06 MPa. Terjadi kenaikan kekuatan tarik yang sangat signifikan dari keadaantanpa pelapisan sebesar 480,04 MPa.
\end{abstract}

Kata kunci: electroplating, kekuatan tarik, Taguchi method, optimasi

\section{ABSTRACT}

SS400 is low carbon steel that been used for industrial construction such as bridge, which is operated in the open environment. Therefore, its mechanical properties and its quality would be decreased along with the time elapsed. In some previous research, it is proofed that electroplating was able to increase the corrosion resistant as well as the tensile strength of the coated steel. Therefore, by electroplated the SS400, hopefully this steel could be improved both of its properties. This research aim to optimize the tensile strength of this steel by electroplating with nickel. The Taguchi method L9 was employed to design the experiments. Variations were made on the electric current, temperature, and the time for the processes, each of them with three levels. Each combination was triple replicated. The steel were manufactured to the shape of tensile samples of ASTM E8 standard prior to coating process. The tensile test machine of Zwick/Roel Z100 was used for tensile test of the samples after coated and compare to the uncoated one. S/N ratio analysis following with ANOVA revealed that temperature, electric current and time of electroplating process contribute to the tensile strength at level of $62.57 \%, 13.63 \%$, and $10.89 \%$ respectively. While the most optimal parameter combination results were the electric current of 3 amperes, temperature of $45^{\circ} \mathrm{C}$, and time to process of 15 minutes with a tensile strength of 610.06 
MPa. A significant increase of tensile strength of this steel was achieved in compare to the uncoated of 480.04 MPa.

Keywords: electroplating, tensile strength, taguchi, optimization

\section{PENDAHULUAN}

D erkembangan teknologi di sektor industri manufaktur yang semakin tahun semakin maju tidak lepas dari proses pengerjaan akhir atau finishing. Salah satu proses pengerjaan akhir di industri manufaktur adalah pelapisan logam. Banyak teknik yang telah digunakan dalam pelapisan suatu material, salah satunya yaitu pelapisan dengan cara listrik atau sering disebut dengan electroplating. Electroplating merupakan suatu proses pelapisan logam dengan media aliran arus listrik direct current (DC) melalui penghantar yang dihubungkan dengan elektroda (anoda dan katoda). Anoda dihubungkan pada bahan pelapis, sedangkan katoda dihubungkan pada bahan yang akan dilapisi dengan media larutan elektrolit. Kualitas logam sangat dibutuhkan dalam industri manufaktur terutama pada bidang konstruksi, kereta api, jembatan, dan lain sebagainya (Irwanto, 2010). Penggunaan material yang bersentuhan langsung dengan lingkungan sekitar akan mengakibatkan penampilan, mutu serta daya guna material mengalami penurunan pada sifatmekanik (Mulyuda dan Mulyanto, 2017). Masa sekarang ini proses pelapisan logam secara electroplating sangat banyak digunakan dengan beberapa bahan pelapis diantaranya yaitu nikel. Pelapisan menggunakan nikel merupakan salah satu solusi untuk mencegah korosi pada permukaan logam, meningkatkan kekuatan material dan menambah decorative material (Ananta dan Sakti, 2016).Penerapan metode pelapisan secara electroplating cocok dalam stamping tooling (Moura et al, 2014). Faktor produksi utama saat kodisi kerja electroplating adalah kebisingan, getaran, kontaminasi, dll (Lazarenkov, A.M., 2019). Oleh karena itu faktor tersebut perlu diperhatikan waktu penelitian dilakukan.

Kualitas pelapisan proses electroplating yang dihasilkan dapat dianalisa menggunakan metode statistika yang telah banyak dikembangkan dan digunakan pada berbagai bidang, salah satunya ialah bidang optimasi. Metode statistika yang biasa diterapkan untuk optimasi adalah Taguchi yang diperkenalkan pertama kali oleh Dr. Genechi Taguchi. Metode Taguchi merupakan salah satumetode yang efektif untuk mengendalikan kualitas produk secara offline, yaitu usaha pengendalian atau perbaikan kualitas yang dimulai dari perancangan hingga pemrosesan suatu produk. Kelebihan dari metode ini adalah tingkat efisiensi rancangan percobaan lebih tinggi karena dapat melakukan penelitian yang yang melibatkan banyak faktor dan level, dan mendapatkan hasil produk yang konsisten terhadap gangguan dari faktor yang tidak dapat dikontrol (Soejanto, 2009).

Dalam penelitian ini penulis melakukan pengujian serta menganalisa terkait pengaruh variasi parameter kuat arus, suhu, dan waktu proses electroplating SS400 menggunakan nikel (Ni). Kekuatan tarik hasil electroplating diukur dan dianalisa menggunakan metode Taguchi untuk menentukan kombinasi variasi parameter yang optimal. Penggunaan material SS400 dalam penelitian ini dikarenakan banyak material yang digunakan pada industri kontruksi yang mengalami patah akibat suatu beban misalnya dalam penerapan SS400 sebagai alat pemotong kulit sepatu (Wardoyo, 2015). Oleh karena itu penulis melakukan eksperimen dengan melapisi logam tersebut untuk meningkatkan kekuatan tarik. Sedangkan penggunaan bahan pelapis nikel dikarenakan nikel memiliki sifat yang ulet sehingga nantinya dapat menambah nilai kekuatan tarik logam yang akan dilapisi,selain itu, juga dapat menghambat terjadinya korosi dan logam semakin tampak indah dan mengkilap. 


\section{METODE PENELITIAN}

a. Waktu dan Tempat Penelitian

Penelitian dilakukan pada bulan Februari sampai dengan bulan Oktober 2019. Penelitian dilakukan di Laboratorium Uji Bahan, Jurusan Teknik Mesin, Fakultas Teknik Universitas Jember.

b. Alat

Alat yang digunakan pada penelitian ini yaitu terdiri dari 3 pokok. Pertama, alat yang digunakan dalam pembuatan spesimen yaitu gergaji potong, jangka sorong, amplas, gerinda, peralatan safety, bor duduk. Kedua, alat yang digunakan dalam proses eletroplating yaitu rectifier, bak plating, rak, heater, pengaduk larutan, termokontrol, stopwatch. Ketiga, alat untuk pengujian yaitu mesin uji tarik Zwick / Roel Z100. Desain alat yang digunakan dalam penelitian ini dijelaskan pada Gambar 1 berikut.

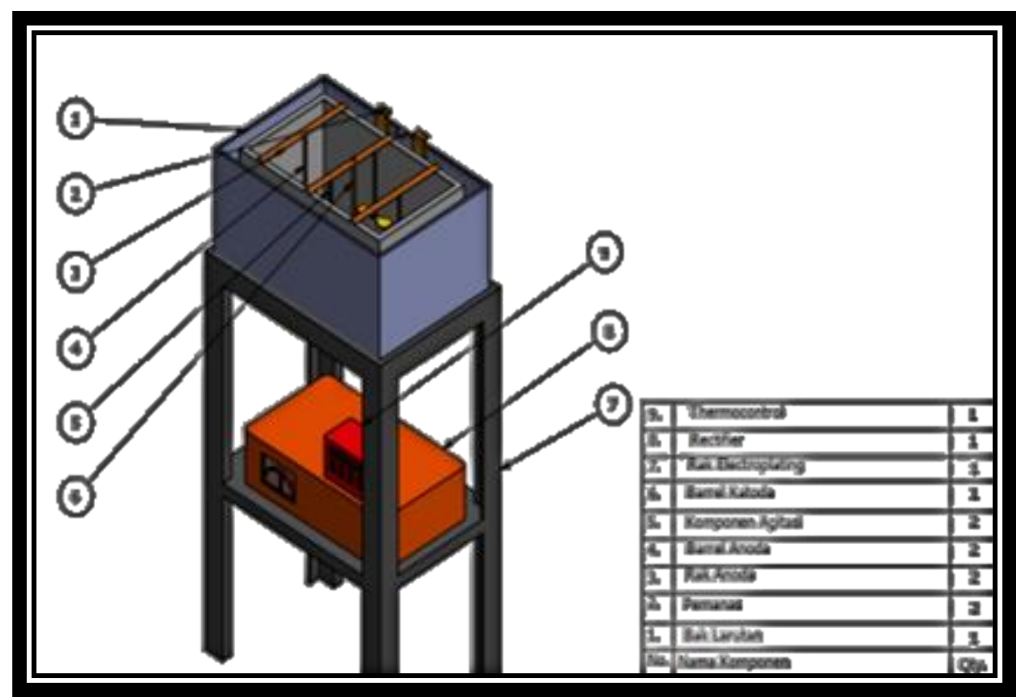

Gambar 1. Desain alat electroplating

c. Bahan

Bahan yang digunakan pada penelitan ini yaitu SS400 sebagai katoda dan nikel sebagai anoda. Autosol digunakan untuk memperhalus permukaan specimen dan menghilangkan kotoran. Aquades, larutan $\mathrm{H}_{3} \mathrm{BO}_{3}$, larutan $\mathrm{NiSO}_{4}$, larutan $\mathrm{NiCl}_{2}$, brightener $\mathrm{Mnt}$, dan brightener MU sebagai bahan pembuatan larutan elektrolit. Pembersihan spesimen SS400 dilakukan terlebih dahulu agar dapat meminimalkan kerusakan substrat sambil menghilangkan kontaminan, debu, dan lainya (Lou and Huang, 2006).

d. Pengambilan Data

Pembuatan spesimen produk electroplating SS400 berukuran $100 \mathrm{~mm} \times 10 \mathrm{~mm} \times 8 \mathrm{~mm}$ sesuai ASTM E8 (ASTM, 2010) yang akan dilakukan pengujian tarik menggunakan mesin uji tarik Zwick / Roel Z100. Setiap kombinasi dilakukan 3 kali replikasi.Gambar 2 merupakan desain ukuran specimen sesuai dengan ASTM E8. 
e. Metode Analisis

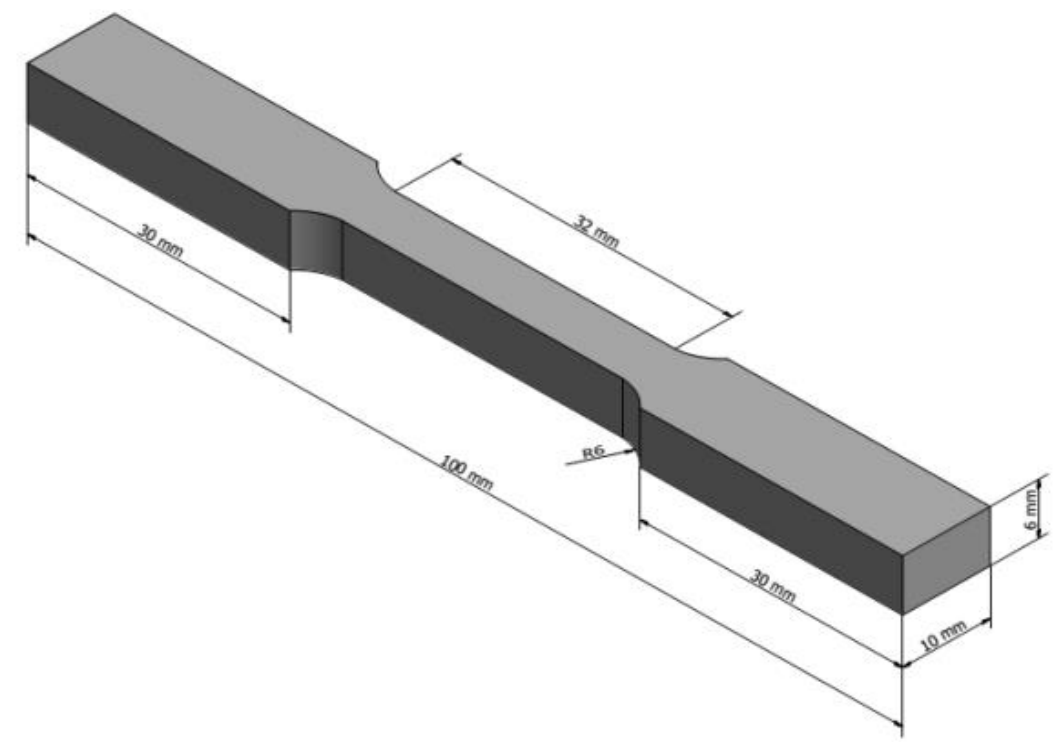

Gambar 2.Dimensi spesimen produk

Desain eksperimen yang digunakan pada penelitian ini menggunakan metode Taguchi orthogonal array $\mathrm{L} 9\left(3^{3}\right)$ yang mempunyai kombinasi 3 parameterdan setiap parameter memiliki 3 level seperti yang ditunjukkan pada Tabel 1 berikut.

Tabel 1.Variabel bebas

\begin{tabular}{ccccc}
\hline Kode & Faktor & Level 1 & Level 2 & Level 3 \\
\hline A & Arus & $1 \mathrm{~A}$ & $3 \mathrm{~A}$ & $5 \mathrm{~A}$ \\
B & Suhu & $45^{\circ} \mathrm{C}$ & $55^{\circ} \mathrm{C}$ & $65^{\circ} \mathrm{C}$ \\
C & Waktu & $5 \mathrm{mnt}$ & $15 \mathrm{mnt}$ & $25 \mathrm{mnt}$
\end{tabular}

Waktu dianggap sebagai faktor yang paling penting dalam proses electroplating yaitu untuk mengidentifikasi berbagai sifat fisik maupun mekanik material (D. Lim, et al, 2020).

\section{HASIL DAN PEMBAHASAN}

1. Data Hasil Eksperimen

Data hasil penelitian ini diperoleh berdasarkan rancangan percobaan menggunakan metode Taguchi berupa matriks ortogonal $\mathrm{L} 9\left(3^{3}\right)$. Parameter yang digunakan memiliki pengaruh terhadap kekuatan tarik.Gambar 3 di bawah merupakan contoh spesimen yang sudah terlapisi. 


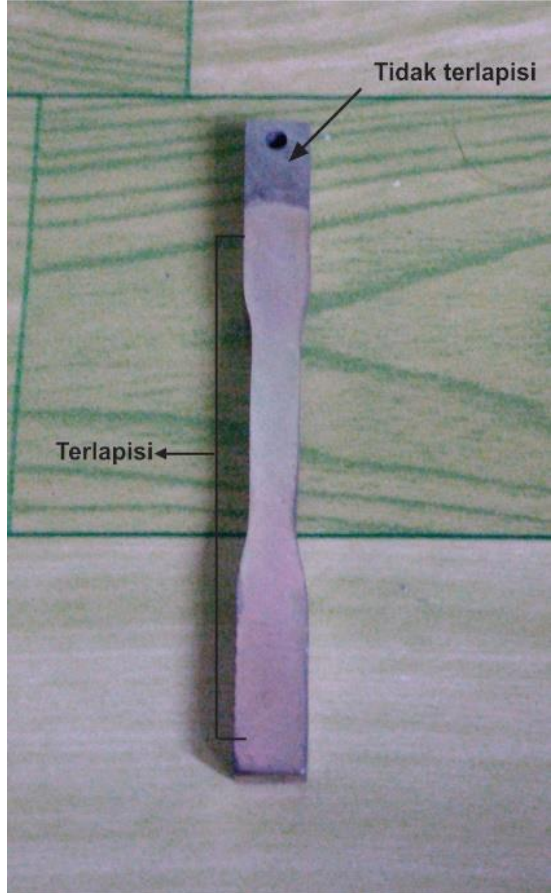

Gambar 3.Contoh spesimen hasil electroplating

Selama pelapisan, specimen digantung dengan pengait melaui lubang, sehingga menyisakan bagian atas tidak dilapisi. Gambar 3 di atas menunjukkan perbedaan rupa antara spesimen yang terlapisi (bagian bawah) dan tidak terlapisi (bagian atas di sekitar lubang pengait). Hasil electroplating baja SS400 menggunakan nikel tampak semakin indah dan mengkilap.

Pada Gambar 4 berikut menunjukkan hasil kekuatan tarik spesimen specimen sebelum di electroplating (raw materia) sebesar $2350 \mathrm{~kg}$. Perhitungan kekuatan tarik maksimal (UTS) pada specimen raw material adalah sebagai berikut:

$\mathrm{UTS}=(\mathrm{F}$ maks $) / \mathrm{A}_{0}$

$\mathrm{UTS}=2350 / 48$

UTS $=48,95 \mathrm{Kg} / \mathrm{mm}^{2}$

UTS $=480,04 \mathrm{MPa}$

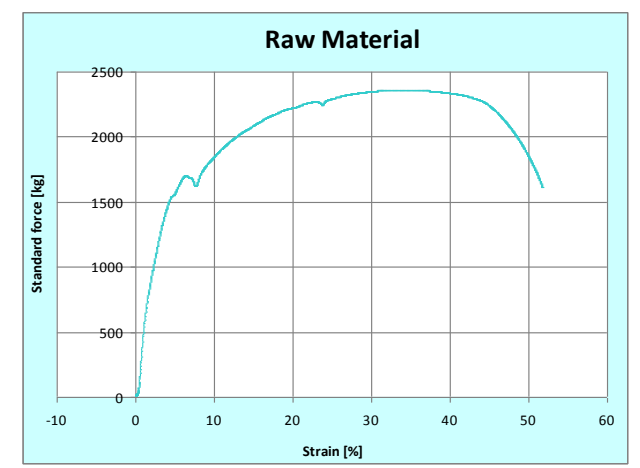

Gambar 4. Kekuatan tarik raw material

Hasil pengujian tarik seluruh eksperimen disajikan pada Tabel 2 sebagai berikut. 
Tabel 2.Data hasil eksperimen

\begin{tabular}{|c|c|c|c|c|c|c|c|}
\hline \multirow{2}{*}{ No. } & \multicolumn{3}{|c|}{ Faktor } & \multirow{2}{*}{ Replikasi } & \multirow{2}{*}{$\begin{array}{l}\text { Fmaks } \\
(\mathbf{K g})\end{array}$} & \multirow{2}{*}{$\begin{array}{c}\text { Kekuatan Tarik } \\
\text { (MPa) }\end{array}$} & \multirow{2}{*}{$\begin{array}{c}\text { Rata-rata } \\
\text { (MPa) }\end{array}$} \\
\hline & $\mathbf{A}$ & B & C & & & & \\
\hline \multirow{4}{*}{1.} & & & & I & 2970 & 606,73 & \\
\hline & 1 & 45 & 15 & II & 3030 & 618,96 & 616,27 \\
\hline & & & & III & 3050 & 623,11 & \\
\hline & & & & I & 2730 & 557,70 & \\
\hline \multirow[t]{3}{*}{2.} & 1 & 55 & 20 & II & 2790 & 569,96 & 563,16 \\
\hline & & & & III & 2750 & 561,82 & \\
\hline & & & & I & 2230 & 455,51 & \\
\hline \multirow[t]{3}{*}{3.} & 1 & 65 & 25 & II & 2170 & 443,26 & 436,46 \\
\hline & & & & III & 2000 & 410,60 & \\
\hline & & & & I & 2990 & 610,85 & \\
\hline \multirow[t]{3}{*}{4.} & 3 & 45 & 20 & II & 3050 & 623,11 & 620,40 \\
\hline & & & & III & 3070 & 627,23 & \\
\hline & & & & I & 3020 & 616,93 & \\
\hline \multirow[t]{3}{*}{5.} & 3 & 55 & 25 & II & 3000 & 612,91 & 616,87 \\
\hline & & & & III & 3040 & 620,76 & \\
\hline & & & & I & 2870 & 586,33 & \\
\hline \multirow[t]{3}{*}{6.} & 3 & 65 & 15 & II & 2850 & 582,22 & 581,89 \\
\hline & & & & III & 2830 & 577,12 & \\
\hline & & & & I & 3060 & 625,17 & \\
\hline \multirow[t]{3}{*}{7.} & 5 & 45 & 25 & II & 2970 & 606,73 & 616,96 \\
\hline & & & & III & 3030 & 618,99 & \\
\hline & & & & I & 3010 & 614,67 & \\
\hline \multirow[t]{3}{*}{8.} & 5 & 55 & 15 & II & 3040 & 620,76 & 620,30 \\
\hline & & & & III & 3060 & 625,27 & \\
\hline & & & & I & 2360 & 482,09 & \\
\hline \multirow{2}{*}{9.} & 5 & 65 & 20 & II & 2210 & 451,49 & 462,02 \\
\hline & & & & III & 2120 & 432,47 & \\
\hline
\end{tabular}

Pada Tabel 2 di atas dapat diketahui bahwa hasil rata-rata kekuatan tarik raw material dengan spesimen yang sudah dilapisi mengalami kenaikan dari 480,04 MPa menjadi 570,48 $\mathrm{MPa}$. Nilai kekuatan tarik masing-masing kombinasi variasi juga mengalami peningkatan, dimana nilai tertinggi didapatkan pada kombinasi ke-4 sebesar 620,40 MPa dan terendah pada kombinasi ke-3 sebesar 436,46 MPa. Pada kombinasi ke-3 mengalami penurunan nilai kekuatan tarik dari hasil raw material karena terlalu tinggi penggunaan suhu dan waktu.

\section{Perhitungan S/N Rasio}

Pada penelitian ini nilai kekuatan tarik semakin besar semakin baik maka pemilihan karakteristik $\mathrm{S} / \mathrm{N}$ rasio yaitu larger the better. Contoh perhitungan $\mathrm{S} / \mathrm{N}$ rasio nilai kekuatan tarik dengan karakteristik nilai kekuatan tarik semakin besar semakin baik pada kombinasi yang pertama yaitu sebagai berikut.

$$
\begin{aligned}
& S / N=-10 \log \left(\frac{1}{n} \sum_{\mathrm{i}=1}^{r} \frac{1}{\mathrm{Y}_{\mathrm{i}}^{2}}\right) \\
& S / N=-10 \log \left(\frac{1}{3}\left[\left(\frac{1}{606,73^{2}}\right)+\left(\frac{1}{618,96^{2}}\right)+\left(\frac{1}{623,11^{2}}\right)\right]\right) \\
& S / N=60,5665
\end{aligned}
$$



berikut.

Perhitungan $\mathrm{S} / \mathrm{N}$ rasio untuk setiap respon di semua kombinasi ditunjukan pada Tabel3

Tabel 3. Data hasil perhitungan $\mathrm{S} / \mathrm{N}$ rasio

\begin{tabular}{ccccc}
\multirow{2}{*}{ Kombinasi Hasil Data Kekuatan Tarik } \\
\cline { 2 - 5 } & $\mathbf{4}$ & $\mathbf{2}$ & $\mathbf{3}$ & S/ N Rasio \\
\hline 1 & 606,73 & 618,96 & 623,11 & 60,5665 \\
2 & 561,82 & 557,71 & 569,96 & 59,7839 \\
3 & 455,51 & 443,26 & 410,61 & 57,5701 \\
4 & 610,85 & 623,11 & 627,23 & 60,6246 \\
5 & 616,93 & 612,91 & 620,76 & 60,5750 \\
6 & 586,33 & 582,22 & 577,12 & 60,0680 \\
7 & 625,17 & 606,73 & 618,99 & 60,5764 \\
8 & 614,87 & 620,76 & 625,27 & 60,6232 \\
9 & 482,09 & 452,49 & 451,49 & 58,0644 \\
\hline \multicolumn{5}{c}{ Maksimal } \\
\cline { 2 - 4 } & Minimal & $\mathbf{6 0 , 6 2 4 6}$ \\
\hline
\end{tabular}

3. Kombinasi variasi optimal

Nilai yang paling optimal didapatkan dari perhitungan nilai rata-rata tiap level. Nilai rata-rata tertinggi merupakan nilai yang paling optimal pada parameter yang digunakan.

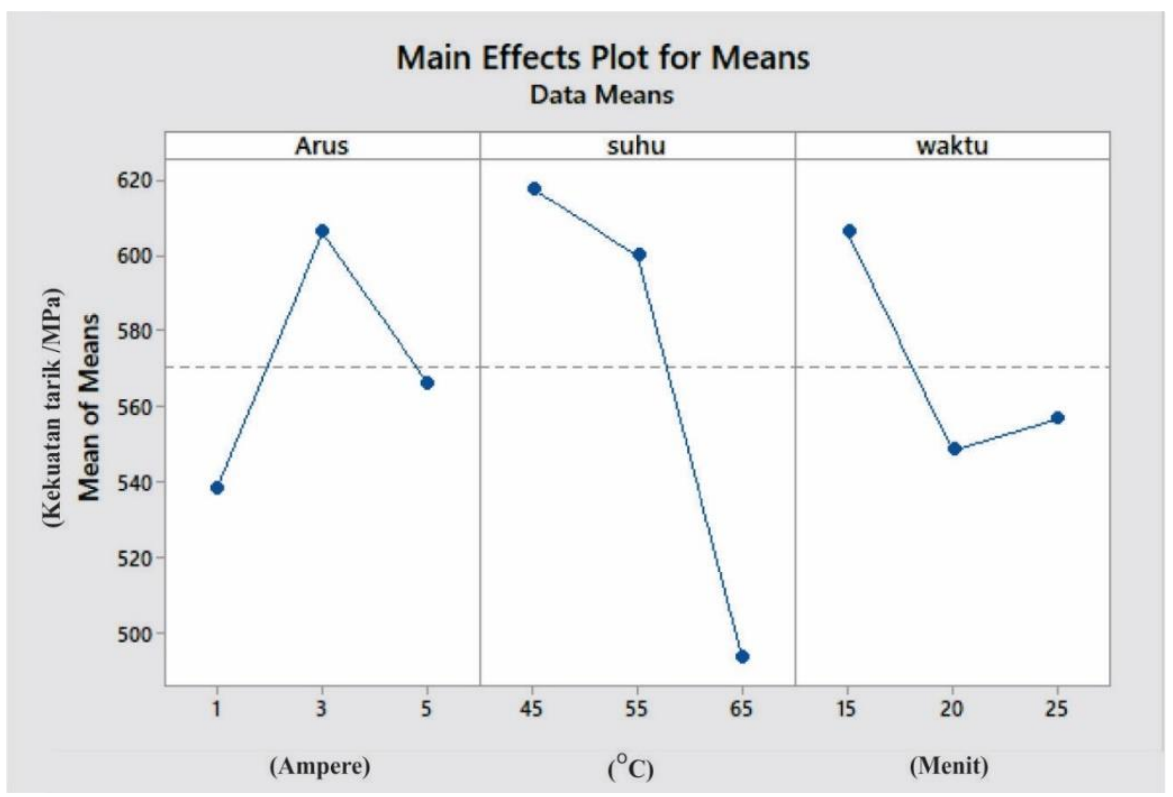

Gambar 5. Nilai plot rata-rata kekuatan tarik tiap level variabel bebas

Nilai yang paling optimal dari level variable bebas proses electroplating dapat diketahui pada nilai rata-rata tertinggi dari masing-masing level yang telah ditunjukkan pada Gambar 5. Sehingga dapat ditentukan kombinasi level yang paling optimal. Kombinasi level paling optimal ditunjukkan pada Tabel 4 di bawah. 
Tabel 4. Kombinasi nilai optimal

\begin{tabular}{cccc}
\hline Kode & $\begin{array}{c}\text { Variabel } \\
\text { bebas }\end{array}$ & Level & Nilai \\
\hline $\mathrm{X}$ & Kuat Arus (A) & 2 & 3 \\
Y & Suhu ( $\left.{ }^{\circ} \mathrm{C}\right)$ & 1 & 45 \\
$\mathrm{Z}$ & Waktu (Min) & 1 & 15 \\
\hline
\end{tabular}

4. ANOVA, Uji F, dan Persentase Kontribusi

ANOVA digunakan untuk mengetahui kontribusi setiap parameter terhadap keluaran yang diteliti. Hasil perhitungan ANOVA didapatkan dari software Minitab 18.Tabel 5 menunjukkan hasil perhitungan ANOVA.

Tabel 5. Hasil Perhitungan ANOVA

\begin{tabular}{ccrrr}
\hline $\begin{array}{c}\text { Variabel } \\
\text { bebas }\end{array}$ & DK & \multicolumn{1}{c}{ SS } & \multicolumn{1}{c}{ MS } & \multicolumn{1}{c}{ F $_{\text {hitung }}$} \\
\hline Kuat arus & 2 & 6959,88 & 3479,94 & 5,22 \\
Suhu & 2 & 27170,09 & 13585,04 & 20,39 \\
Waktu & 2 & 5827,66 & 2913,83 & 4,37 \\
Residual & 2 & 1333,00 & 666,40 & \\
Total & 8 & 41290,00 & & \\
\hline
\end{tabular}

Nilai $F_{\text {tabel }}$ pada penelitian ini sebesar 19,00. Dapat dilihat bahwa nilai $F_{\text {hitung }}$ parameter suhu adalah 20,39.Dapat disimpulkan bahwa pada tabel nilai $F_{\text {hitung }}>F_{\text {tabel }}$ maka nilai tersebut mempunyai pengaruh yang signifikan. Hal tersebut menunjukkan suhu memiliki pengaruh yang signifikan terhadap nilai kekuatan tarik. Sedangkan parameter arus dan waktu tidak memiliki pengaruh yang signifikan terhadap nilai kekuatan tarik produk electroplating karena nilai keduanya memiliki $\mathrm{F}_{\text {hitung }}<\mathrm{F}_{\text {tabel. }}$. Hal tersebut dikarenakan kenaikan kekuatan tarik disebabkan oleh banyaknya ion yang mengendap pada katoda dan merata. Sedangkan parameter yang berfungsi lebih dalam proses pengendapan adalah suhu. Oleh karena itu parameter suhu lebih berpengaruh siginifikan dibandingan dengan arus dan waktu.

Persen kontribusi dari tiap variabel bebas yang digunakan terdapat pada Tabel 6 dengan contoh perhitungannya adalah sebagai berikut:

$$
\begin{aligned}
& \mathrm{SS}_{\mathrm{A}}^{\prime}=\mathrm{SS}_{\mathrm{A}}-\mathrm{MS}_{\mathrm{e}}\left(\mathrm{DK}_{\mathrm{A}}\right) \\
& \mathrm{SS}_{\mathrm{A}}^{\prime}=6959,88-666,4(2) \\
& \mathrm{SS}_{\mathrm{A}}^{\prime}=5627,08 \\
& \rho_{\mathrm{A}}=\frac{\mathrm{SS}_{\mathrm{A}}^{\prime}}{\mathrm{SS}_{\mathrm{T}}} \times 100 \% \\
& \rho_{\mathrm{A}}=\frac{5627,08}{41290,48} \times 100 \% \\
& \rho_{\mathrm{A}}=13,62
\end{aligned}
$$

Tabel 6. Persen kontribusi tiap variabel bebas

\begin{tabular}{ccrc}
\hline Kode & Variabel bebas & \multicolumn{1}{c}{ SS' $^{\prime}$} & P (\%) \\
\hline$X$ & Kuat Arus & 5627,08 & 13,63 \\
Y & Suhu & 25837,29 & 62,57 \\
$Z$ & Waktu & 4494,86 & 10,89 \\
R & Residual & & 12,91 \\
\hline \multicolumn{4}{c}{ Total } \\
\hline
\end{tabular}


Pada Tabel 6 di atas dapat diketahui bahwa parameter suhu adalah parameter yang paling berkontribusi dalam penelitian ini. Hal tersebut dikarenakan selisih rata-rata kekuatan tarik pada parameter suhu sangat jauh dibandingkan dengan parameter arus dan waktu.

\section{Reaksi Kimia pada Proses Electroplating} berikut:

Skema terjadinya reaksi kimia pada proses electroplating dapat dilihat pada Gambar 6

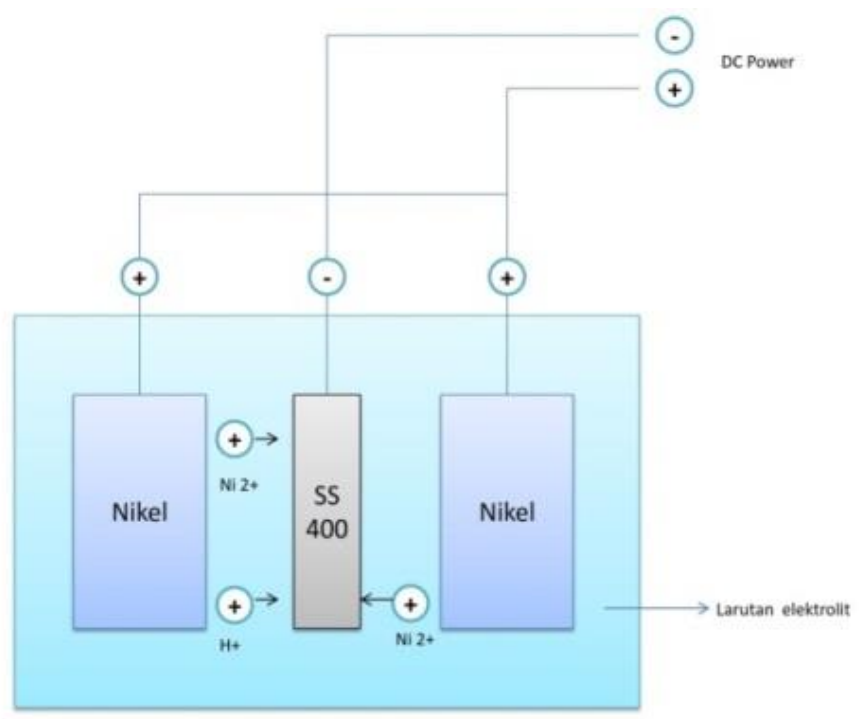

Gambar 6. Reaksi kimia proses electroplating

Reaksi yang terjadi pada elektroda yaitu sebagai berikut:

1. Reaksi pada anoda (Nikel)

$\mathrm{Ni}(\mathrm{s})+2 \mathrm{e} \rightarrow \mathrm{Ni}^{2+}(\mathrm{I})$

Pada anoda terjadi proses oksidasi yaitu pelepasan ion $\mathrm{Ni}$ (s) yang kelebihan muatan

+ sehingga membutuhkan muatan negatif dan menjadi $\mathrm{Ni}^{2+}(\mathrm{I})$ dalam larutan elektrolit.

2. Reaksi pada katoda (SS400)

$\mathrm{Ni}^{2+}(\mathrm{I})+2 \mathrm{e} \rightarrow \mathrm{Ni}(\mathrm{s})$

Pada katoda terjad proses reduksi yaitu penerimaan ion $\mathrm{Ni}^{2+}$ (I) yang sudah terlarut dalam larutan elektrolit. Katoda yang teraliri oleh arus bermuatan negatif menjadikan $\mathrm{Ni}^{2+}$ (I) dalam larutan elektrolit terdeposit pada katoda menjadi $\mathrm{Ni}$ (s).

Katoda merupakan benda yang akan dilapisi (terminal negatif), sedangkan anoda adalah bahan pelapis yang akan terlarut dalam larutan elektrolit (terminal positif) yang kemudian akan menempel pada katoda (Kanani, 2004).

\section{Pembahasan}

Kenaikan nilai kekuatan tarik penelitian ini diakibatkan dengan banyaknya endapan ionion yang menempel pada benda kerja pada proses electroplating, selain itu juga tingkat kerataan endapan ion-ion yang menempel. Pengaruh parameter terhadap kekuatan tarik proses electroplating adalah sebagai berikut:

a. Suhu

Pada penelitian ini, parameter suhu merupakan parameter yang paling berpengaruh signifikan terhadap nilai kekuatan tarik, dengan nilai persen kontribusi $62,57 \%$. Nilai paling optimal yaitu pada level $1\left(45^{\circ} \mathrm{C}\right)$ sebesar $617,99 \mathrm{MPa}$. Pada penelitian ini 
semakin besar suhu tidak menjadikan nilai kekuatan tarik juga meningkat. Hal tersebut dikarenakan ion-ion yang terlepas dari anoda (oksidasi) akan mengalami tumbukan antar ion dengan cepat, sehingga penggunaan suhu yang lebih besar mengakibatkan ion-ion tadi tidak dapat menempel pada benda kerja yang akan dilapisi dengan merata. Pembahasan di atas sejalan dengan Rasyad dan Arto (2018) yang menjelaskan bahwa ketika suhu dinaikkan nilai kekuatan tarik justru menurun.

b. Arus

Arus juga merupakan parameter yang kurang berpengaruh terhadap nilai kekuatan tarik. Nilai optimal yang didapatkan yaitu pada level 2 (3 Ampere) sebesar 606,38 MPa. Pada penelitian ini semakin tinggi arus juga tidak menjadikan nilai kekuatan tarik akan meningkat. Hal tersebut dikarenakan ion-ion yang terlepas dari anoda (oksidasi) dan ion-ion yang mengendap pada katoda (reduksi) disebabkan dengan adanya arus. Oleh karena itu diperlukan arus yang tepat agar ion-ion tadi tidak berguguran dan berjatuhan. Hal ini sejalan dengan hasil Sukarjo dan Pani (2018) bahwa kuat arus yang tidak sesuai akan meyebabkan pengendapan kurang mengikat dengan kuat. Akibatnya, endapan tidak maksimal dan ion-ionakan berguguran dan berjatuhan. Pada akhirnya, ion-ion tidak menempel pada benda kerja yang akan dilapisi.

c. Waktu

Pada penelitian ini, waktu juga merupakan parameter yang paling kecil pengaruhnya terhadap nilai kekuatan tarik. Nilai optimal yang didapatkan yaitu pada level 1 (15 menit) sebesar 606,15 MPa. Semakin lama waktu yang digunakan juga tidak menjadikan nilai kekuatan tarik meningkat. Hal tersebut dikarenakan adanya kejenuhan pada larutan elektrolit yang digunakan sebagai media pelapisan. Selain itu, semakin lama penggunaan larutan elektrolit akan mengakibatkan daya guna serta mutu larutan tersebut akan menurun. Sehingga tidak dapat meneruskan ion-ion yang terlepas untuk diendapkan pada benda kerja yang akan dilapisi. Hasil senada dihasilkan oleh Sari, N.H., dkk (2015). Mereka menyebutkan bahwa kekuatan tarik tertinggi yang didapatkan yaitu pada pada waktu 15 menit (level terkecil).

\section{KESIMPULAN}

Hasil pengujian tarik terhadap specimen berbahan SS400 yang dilapisi dengan nickel secara electroplating dengan metode Taguchi dapat diambil beberapa keimpulan. Pertama, proses electroplating dapat menaikkan kekuatan tarik baja SS400 dari $480.04 \mathrm{MPa}$ menjadi rata-rata 610,06 MPa. Kedua, nilai kontribusi pengaruh parameter terhadap kekuatan tarik produk electroplating baja SS400 menggunakan nikel adalah pada parameter suhu sebesar $62,57 \%$, kuat arus sebesar 13,63\%, dan waktu sebesar 10,89\%. Ketiga, kombinasi parameter paling optimal nilai kekuatan tarik yang diperoleh yaitu pada kuat arus 3 ampere sebesar $606,38 \mathrm{MPa}$, suhu $45^{\circ} \mathrm{C}$ sebesar $617,88 \mathrm{MPa}$, dan waktu 15 menit sebesar $606,15 \mathrm{MPa}$.

\section{SARAN}

Beberapa saran untuk penelitan selanjutnya dan perlu diperhatikan. Pertama, penelitian lanjutan tentang electroplating dapat dilakukan dengan menggunakan parameter yang berbeda, dan melakukan pegujian laju korosi ataupun daya lekat pelapisan. Kedua, ada baiknya dilakukan uji kebenaran hasil ini dengan menggunakan metode eksperimen yang berbeda, misalnya Response Surface Methodology (RSM).

Selain itu ada dua saran yang bersifat teknis jika hendak melakukan electroplating. Pertama, lakukan preparasi material sebelum dilapisi dengan lebih baik lagi, sehingga 
memperoleh hasil pelapisan logam yang lebih baik. Kedua, pada proses electroplating suatu bahan atau material yang akan dilapisi perlu menjaga kestabilan arus, dan suhu.

\section{DAFTAR PUSTAKA}

Ananta, R.H. dan Sakti, A.M. 2016. Pengaruh Variasi Waktu Celup dan Kuat Arus terhadap Ketebalan Permukaan dan Struktur Mikro Baja ST 41 pada Proses Pelapisan Nikel. JTM. 4(3): 479-488.

ASTM E8. 2010. Standart test methods for tension testing of metallic materials. Thu jul 15. Edisi 2010

D. Lim, B. Ku, D. Seo, et al. 2020. Pulse - Reverse Electroplating of Chromium from Sargent Baths: Influence of Anodic Time on Physical and Electrochemical Properties of Electroplated Cr. International Journal of Refractory Metals and Hard Materials. https://doi.org/10.1016/j.ijrmhm.2020.105213

Irwanto.2010. Pengaruh Jarak Anoda-Katoda dan Pemerata Arus terhadap Ketebalan Lapisan dan Efisiensi Katoda pada Elektroplating Tembaga Asam untuk Baja Karbon Sedang.Skripsi. Universitas Lampung. Lampung.

Kanani, N. 2004.Electroplating; Basic principles, processes and practice, Elsevier advanced technology. Oxford. U.K

Lazarenkov, A.M. 2019. A Study of Working Conditions in Electroplating Shops.Faundry Production and Metallurgy.No. 3. Pp. 160-162.

Lou, H.H and Huang. Y. 2006. Electroplating.Department of Chemical Engineering and science. USA.

Moura, R.L.C., Grandinetti, F.J., and Nohara, E.L. 2014.Feasibility Study of ChromiumElectroplating Process in Stamping Tooling.Academic Journals. Vol. 9 (15)

Mulyuda dan Mulyanto, T. 2017. Pengaruh Tebal Pelapisan Chrom terhadap Sifat Mekanik pada Baja SS400 dengan Metode Elektroplating. Jurnal Teknik FTUP. 30(1).

Rasyad, A., dan Arto, B. 2018. Analisis Pengaruh Temperatur, Waktu, dan Kuat Arus Proses Elektroplating Terhadap Kuat Tarik, Kuat Luluh, dan Kekerasan pada Baja Karbon Rendah. Jurnal Rekayasa Mesin. 9(3): 173-182.

Sari, N.H., Okariawan, I.D.K., dan Darmawan D.P, A.S. 2015.Pengaruh Variasi Kuat Arus Listrik dan Waktu Proses Electroplating Terhadap Kekuatan Tarik, Kekerasan, dan Ketebalan Lapisan pada Baja Karon Rendah dengan Krom.Jurnal Dinamika Teknik Mesin. (5)2.

Soejanto, I. 2009. Desain Eksperimen dengan Metode Taguchi.Graha Ilmu.Yogyakarta.

Sukarjo, Hb. dan Pani, S. 2018. Pengaruh Kuat Arus Listrik dan Waktu Electroplating NickelChrom Terhadap Ketebalan Lapisan pada Permukaan Baja Karbon Rendah. Jurnal Engine. 2(1)

Wardoyo, H. 2015. Analisis Pengaruh Perlakuan Panas Terhadap Kekerasan dan Struktur Mikro Material S45C dan SS400 yang Digunakan Sebagai Alat Potong Kulit Sepatu. Jurnal Teknik Mesin (JTM). Vol. 04 No. 3. 